\title{
AFTER BEETHOVEN
}

\section{Carissa Pobre}

carissapobre@gmail.com

\section{About the Author}

Carissa Pobre graduated from the Ateneo de Manila University with a BFA in Creative Writing. Her work has recently been published in previous issues of High Chair and Kritika Kultura. She is also a recipient of the Loyola Schools Awards for the Arts. At present, she works in corporate sustainability. 
The word "after" holds onto the imposition that things move on. But I wish to dismantle this proposition: once we begin to talk about "after," nothing more than nothing can be said. It should not be difficult to conceive this, we have no source of contentment. There are tools available to us which may dislodge the insufficiencyby retelling ourselves a stranger's kind word, or a false memory-but we could never sustain their usefulness or prolong how they make us feel. Eventually, something in them goes dead. We constantly have to reinvent our understanding to tell ourselves that things can change. And it depends if we live long enough (or one feels that he or she has lived long enough). Even that hope would defeat us.

Either that or we get stunted. This is the type of behavior that the after often poses, wherein much of where we are is impossible to refresh. Edmond Jabés has a parallel term for this in writing, called "The Book of Torment," which he referred to as the space between projects wherein one feels that one will never write again. I myself have felt it. Whatever came out on the page was one contending attempt after the other. When we reach an end, possibilities start to gather as if a promise that we can do it again, or do more, but this is not inherent to the after, and some people tend to confuse it with progress. We would have all felt nothing at one point in our lives.

Others are more generous about it. They recognize that space of the "after" as a perpetual haunting in the search for what comes next, which is an illusion, but they don't discount the sincerity in asking. In the third section of her book Plainwater, Anne Carson plays out this sense of the "after" when an afterword follows the end of a complex narrative of a fake woman named Anna:

After a story is told there are some moments of silence. Then words begin again. Because you would always like to know a little more. Not exactly more story. Not necessarily, on the other hand, an exegesis. Just something to go on with. After all, stories end but you have to proceed with the rest of the day. (88)

Carson offers somewhat of a reprieve after the long-winded narrative, played out in 53 fragments, one layer of story upon another. She chooses not to leave us (the readers) in the zone of torment upon reaching the end of the story. This is because Carson is aware that an end would never feel to us fully sufficient, and as the space of the "after" here is given voice, she offers us a gift. "You do not know how this vague wish of yours fills me with fear," she confesses. "I have been aware of it from the beginning." (88)

I can't say this voice has made it easier for me, and it's not that I couldn't take more for myself.

We should not discount that the cost of the "after" is the assertion that whatever came before is a fact. That is something you cannot play out. 
This is Sergei Rachmaninoff's Vocalise: a song without words. The young pianist played it in the concert hall-it must be deluded to say he was playing it for me. There is some music that carries with it a sense of ongoing time, but other melodies have no intention to prepare us. I expected too much. Nothing moves. After all, it was only an exercise for voice. How do you propose that I gather myself again?

Beethoven (1770-1827) is considered the greatest of all composers. Because this is a cliché, it might be easy to say it isn't true. Or we may accept it right away without thought to listen; a cliché is a form of language wherein the content has gone dead, and for writers, the truth it carries haunts each utterance so as to be significantly altered. What is considered truth is synonymous with fact, and any writerly process seems to want to reinvent the facts which is synonymous with convincing oneself of another truth. In reality, it doesn't leave you with much to go on.

Any composition is a confrontation between the facts and one's perspective, however, as Theodor Adorno writes. We can say that Beethoven did this the best, a feat which should be present in three of his most famous works: the Moonlight Sonata, the Fifth Symphony, and Piano Sonata No. 9, commonly known as the Pathetiqué.

Although Moonlight Sonata is Piano Sonata No. 14's common name, it was originally labelled "sonata quasi una fantasia," which translates to "sonata almost a fantasy." Critics have argued over the popular name, calling it out as a misguided Romantic interpretation-as if the image of moonlight supplemented what lacked in the word "almost," thus stretching it to a form of completion. This prior knowledge could stir in the listening process a real fantasy, even if the image occurred after the fact. Only a shift in perspective, in which one is disillusioned from the added implications of "moonlight," would see that the composition obviously gropes, and that the alteration is fake.

There is proposed originality in what we call a fact, yet we seem to take even the artificial things for ourselves. A poet had once ascribed Beethoven's sonata almost a fantasy to moonlight, and I must say he likely corrupted the music even a little.

"A death without corruption is the promise of photography" is a sentence from Rosmarie Waldrop's Reluctant Gravities (192). Likewise, Roland Barthes had the idea that the accident of a photograph was a wound. It must have hurt us when we began to have a sense of photography. Now beauty makes me feel restless. Nothing is banal anymore. 
I can't imagine many children would go through these years without hearing the first four notes of Beethoven's Fifth Symphony. I was not familiar with the Pathetiqué, until a friend gave me the sheet music for the second movement some time in high school, simplified enough for grade three piano, and even I could play it. I discovered the melody and taught the notes to myself. Whenever I listen to it, it convinces me that time moves.

The account: My grandmother worked in a pharmacy and owned a small print shop in front of our old house in Maria Cristina. I've never gone back there, I wouldn't remember much even if I did, but they said the house was replaced by a condominium painted sky blue with four floors.

My grandmother was nine when the Second World War happened. Her only vivid memory of the war, she recounted, was when a young Japanese soldier sat at their kitchen table across her father for hot soup one afternoon. The three of them passed the hour together. He was very polite, she described to me, and respectful.

After the young soldier left (he bowed), my grandmother saw that he had forgotten a small package he'd brought with him, wrapped in paper and string, and her father had her rush to the train station where he left for, running quickly as a nine-year old child could. She managed to reach him there. The young man smiled at her, and he told her to take care on the way back, and to thank her father, too.

For some reason, whenever I ask my grandmother about this story, I tend to filter the scene in black and white, as in a film. I imagine their faces and see expressions that are infinitely peaceful. The historian has glassy eyes, but they can travel far.

The Japanese had their war music, too. Although members of the Manila Symphony Orchestra refused to participate in the Occupation's musical program, their principal conductor was arrested and they were forced into the "New Philippines Symphony Orchestra" in 1941. This was a prosperous time for Filipino indigenous and European classical music alike, as the work of musicians and artists was strongly encouraged in developing the "high" culture considered essential for the creation of the Greater East Asia Co-Prosperity Sphere.

Between music and propaganda is often an exclamation of newness. Can the music go on without holding it? Sometimes everything is connected. Other times these connections are merely banal. 
Or to begin again: "Reconstruct how I heard Beethoven as a child." This is a single fragment from Adorno's major text on Beethoven, published posthumously in 1998 (3). As the first sentence of his introduction, it says something of Adorno's perspective on his experiences of Beethoven, wherein the formal composition plays out more like a catalogue of brief entries than a sweeping study of the music. Adorno recounts these experiences in the assertion that they are largely fragmentary, just as one's experience of music feels largely indefinite. There are some melodies without intention to prepare us. This makes a piece feel more intimate at times.

What interests me about this as a first sentence is its articulation as an imperative given the verb, "reconstruct." Adorno does not have to tell us that he will go on to do this, and the result seems self-referential. The fact that he must utter it suggests he has to convince himself this will be the subsequent activity - the account does reach 193 pages. This is complicated by a contingent perspective of the articulation as instructive, that in order to direct himself and his writerly project he needs to tell himself to do it, he cannot simply begin. So if I had to read this first sentence, "Reconstruct how I heard Beethoven as a child," I would have to do it myself.

The sentence also reveals that an extent of Adorno's project is reconstruction. To re-member some construction, as it were, implicates that it once felt whole.

The Greek language has a word for the whole shape of ideas-asserting that ideas do have a shape-called "morphe," and we grasp an extent of this morphe when the awareness of a thing first happens in our consciousness. The shape may appear somewhat blurred or unbounded, but of course, the point is not that there is nothing.

According to Adorno, what Beethoven achieved was a state of the music in which it was whole, even if that whole seems like nothing:

Beethoven may represent an attempt to circumvent the ban on images. His music is not an image of anything, and yet is the image of the whole: an imageless image. (8)

This must tell us two things: imagelessness has a form, it must be possible to know its shape. 
This may not be true at all. At the very least, we know that a dead language can gape open like a wound. There are days when I suddenly find myself, out of all places, in a church from aimlessly walking-I've rarely believed in anything remotely supernatural for too long. But I swear that just sitting there, if I stare at the crucifix long enough, it makes me cry. I don't know how it happens. I start talking to God. I tell him that I have problems and so on.

I suppose this goes for some of us whose religion has no sense. Because there are punishing pleasures to having a god, and that way, we can thrash as little creatures in the world wildly and suffer further. We seem to validate our pain for nothing, or more of it. We look to the divine to continue satisfying us, yet take pleasure later on in calling out God as a fake.

I don't want to say crying then was entirely artificial. Does my lack of conviction render that response dead?

These days, it is easier to hold onto a voice than a body. Even if it is just my selfconsciousness ringing in my ear.

The practice of music engenders self-importance in certain parts of history. One side would say this, as when the violinist Jascha Heifetz insisted on playing Richard Strauss to a Jewish audience in 1953. Then someone went into his hotel room after the recital and beat on his violin with a crowbar. I can't say I understand why anyone would do this-not Strauss in Jerusalem, more so that year. All suffering must be valid, even if its language is private, or because it is. So whatever follows just feels like willfully causing someone to hurt.

There are ideas that lose their validity over time. This was how the pianist and conductor Daniel Barenboim rationalized how he disturbed the historical landscape when he played Richard Wagner at a national music festival in Israel in 2001. Barenboim himself is part Israeli, the other half Argentinian. He explained in an interview:

I understand that a survivor of the concentration camps cannot deal with hearing some of the music because of some of their associations. But I cannot accept that he has the right to sit in Tel Aviv and suffer because he knows I am playing Wagner in Jerusalem. (“Spaces of Dialogue," The Frost Interview, Al Jareeza) 
Yes, there is no connection. Of course Wagner did not invent anti-Semitism, nor did Hitler. Does it make it easier in Tel Aviv because of relational distance when the performance occurs as a fact? We know that a fact can inflict on the self a wound of whatever has been.

(In the same interview, Barenboim narrated how his grandparents first met each other on a boat to Argentina and had to marry in order to depart into the main city. Back then, it was impossible to let off citizens who were travelling without family, and it was the only thing that the captain could do. They would not see each other again until after two years, but when they met, they fell in love and were already married. There are beautiful endings, yes. There are things that can help us go on.)

"I will tell you something else," Barenboim continues:

We know that [Hitler] had the capacity to go to a performance of Lohengrin (opera by Wagner) and be moved to tears. How is that possible? How is it possible that he can be such a monster and murder so many people and feel the beauty and the nobility of the music? There is only one answer and that is there was no connection between the two. ("Spaces of Dialogue")

These scenarios might make it easy for us to say that something within the music is pure. What seems pure can merely be vacuous. There is that idea that we can be "moved" by the aesthetic or the abstract, even in a loss of context, which is either selfalienation, or forgetting ourselves-even just for a moment, we come from nothing. The fact is, this accusation can still be offered up as a gift. Music is made of nothing. We take for ourselves what we will.

As we know, drawn out periods of conflict tell us that we cannot forget. But music does not always repeat itself. It makes use of modulation, variations in a prospective coda, a different key, because music insists that things can change. It's not just about newness. It is a form of ceaseless reconstruction.

I can't help but think how, once we stop imagining, it is the facts that matter and nothing else. And I don't think an artistic statement or commentary could rescue imagelessness from context-music has to do it itself. For the "after" has no sensible language. There are spaces where the intellect has no place. Not even emotion. Not even the thought that there could be something else. 
At any moment, the pleasure once derived from the site of intellectual experience will overturn, slipping on the ephemeral. Because all of us, including intellectuals, would like some assurance that we can transcend our life. When I speak of affection, for instance, I want that to be genderless. And I have this secret, irrational wish that philosophy would account for me. Not the large, wide scale of Being. I don't want to be satisfied with the iterations-account for me as a person. 


\section{Works Cited}

Adorno, Theodor. Beethoven: The Philosophy of Music. Trans. Edmund Jephcott. Ed. Rolf Tiedemann. Polity P: Cambridge, 1998. Print.

Barenboim, Daniel. “Spaces of Dialogue." The Frost Interview. Al Jareeza. By David Frost. 29 Oct. 2013. Web. 9 Sept. 2014.

Carson, Anne. Plainwater. Vintage Books: New York, 1995. Print.

Waldrop, Rosmarie. Curves to the Apple. New Directions: New York, 2006. Print. 